\title{
Association study of relationships of polymorphisms in the miR-21, miR-26b, miR-221/222 and miR-126 genes with cervical intraepithelial neoplasia and cervical cancer
}

Jia Yang ${ }^{1 \dagger}$, Zhiling Yan ${ }^{2 \dagger}$, Yingying Wang ${ }^{1}$, Jinmei $\mathrm{Xu}^{2}$, Rui $\mathrm{Li}^{3}$, Chuanyin $\mathrm{Li}^{1}$, Shuyuan Liu', Li Shi ${ }^{1 *}$ and Yufeng Yao ${ }^{1,4^{*}}$

\begin{abstract}
Background: miR-21, miR-26b, miR-221/222 and miR-126 play crucial roles in cervical cancer development. Studies have shown that polymorphisms in miRNA genes can affect miRNA expression, which might be associated with cancer development.

Methods: Ten single-nucleotide polymorphisms (SNPs) in the miR-21, miR-26b, miR-221/222 and miR-126 genes (rs1292037, rs13137 in miR-21; rs2227255, rs2227258 in miR-26b; rs2858061, rs34678647, rs2858060, rs2745709 in miR221/222; rs2297537, rs2297538 in miR-126) were selected, and genotyped in a total of 2176 individuals, including 435 patients with cervical intraepithelial neoplasia (CIN), 743 patients with cervical cancer (CC) and 998 healthy persons using TaqMan assays, and their associations with CIN and CC were evaluated.
\end{abstract}

\footnotetext{
*Correspondence: shili.imb@gmail.com; leoyyf@gmail.com; yufeng_yao@imbcams.com.cn

${ }^{\dagger}$ Jia Yang and Zhiling Yan contributed equally to this work.

'Institute of Medical Biology, Chinese Academy of Medical Sciences \& Peking Union Medical College, Kunming 650118, Yunnan, China

Full list of author information is available at the end of the article
}

C C The Author(s). 2021 Open Access This article is licensed under a Creative Commons Attribution 4.0 International License, which permits use, sharing, adaptation, distribution and reproduction in any medium or format, as long as you give appropriate credit to the original author(s) and the source, provide a link to the Creative Commons licence, and indicate if changes were made. The images or other third party material in this article are included in the article's Creative Commons licence, unless indicated otherwise in a credit line to the material. If material is not included in the article's Creative Commons licence and your intended use is not permitted by statutory regulation or exceeds the permitted use, you will need to obtain permission directly from the copyright holder. To view a copy of this licence, visit http://creativecommons.org/licenses/by/4.0/ The Creative Commons Public Domain Dedication waiver (http://creativecommons.org/publicdomain/zero/1.0/) applies to the data made available in this article, unless otherwise stated in a credit line to the data. 
Results: Our results showed significant differences for the rs2297538 genotypes between the CIN and CC groups $(P=0.001)$. In addition, our results also showed significant differences for the rs 2297537 alleles between the CIN and CC groups $(P=0.003)$, and the $C$ allele of rs 2297537 might be associated with a decreased risk of CC $(O R=0.72$, 95\% Cl: 0.58-0.90). At the inheritance analysis, between the CIN and control groups, the T/T-T/C genotype in rs1292037 and A/A-A/T genotype in rs13137 might be associated with an increased risk of CIN in the recessive model $(\mathrm{OR}=1.61,95 \% \mathrm{Cl}: 1.17-2.20$ and $\mathrm{OR}=1.58,95 \% \mathrm{Cl}: 1.15-2.15)$. In addition, the C/C-T/T genotype of rs2745709 might be associated with a decreased risk of CIN in the overdominant model $(\mathrm{OR}=0.66,95 \% \mathrm{Cl}$ : $0.52-$ 0.82). Between, CIN and CC group, the T/T-C/C genotype in rs 1292037 and A/A-T/T genotype in rs 13137 might be associated with an increased risk of $C C$ in the overdominant model $(\mathrm{OR}=1.43,95 \% \mathrm{Cl}: 1.12-1.81$ and $\mathrm{OR}=1.42$, 95\% Cl: 1.12-1.80). The rs $2297538 \mathrm{G} / \mathrm{G}-\mathrm{A} / \mathrm{G}$ genotype might be associated with an increased risk of CC in the recessive model ( $\mathrm{OR}=2.83,95 \% \mathrm{Cl}: 1.52-5.25)$. The $\mathrm{rs} 22975372 \mathrm{C} / \mathrm{C}+\mathrm{C} / \mathrm{G}$ genotype might be associated with a decreased risk of CC (OR $=0.71,95 \%$ Cl: 0.57-0.89) in the log-additive model. The rs2745709 T/T-C/C genotype might be associated with an increased risk of CC $(\mathrm{OR}=1.44,95 \% \mathrm{Cl}: 1.13-1.83)$ in the overdominant model.

Conclusion: Our results indicate that rs2297538 and rs2297537 in miR-126, rs1292037 and rs13137 in miR-21, and rs2745709 in miR-221/222, may have important roles in the development of CIN or CC.

Keywords: Cervical intraepithelial neoplasia (CIN), Cervical cancer (CC), MiRNA, Single-nucleotide polymorphisms (SNPs), Chinese population

\section{Backgroud}

Cervical cancer $(\mathrm{CC})$ is the leading cause of death from cancer in women worldwide, especially in developing countries [1]. Persistent infection with high-risk human papillomavirus (HR-HPV) is necessary for the development of CC [2]. The progression of cervical cancer can be divided into two main steps, cervical intraepithelial neoplasia (CIN) and CC [3]. In addition to HR-HPV, host genetic factors, such as miRNAs, play important roles in the development of CIN and CC [4].

MiRNAs are a class of small, noncoding singlestranded RNA molecules with approximately 20-24 nucleotides in length [5]. MiRNAs function as the regulators in cell biological process [6], especially in the development of human cancers $[7,8]$, including CC [9, 10]. Several studies revealed that $m i R-21, m i R-26 b, m i R-$ $221 / 222$ and $m i R-126$ are dysregulated in CC tissues and function as either tumour suppressors or tumour promoters in CC [11-16]. For example, miR-126, which is a tumour suppressor in CC, inhibits cell proliferation, migration and invasion by regulating various target genes and signalling pathways $[17,18]$.

Single-nucleotide polymorphisms (SNPs) are the most common type of human heritable variation [19]. SNPs in miRNA genes may affect the mature miRNA level or the binding of miRNAs to their target genes, and finally be related to the development of cancers [20-22]. In 2019, our previous study found that rs 4636297 in $m i R-126$ is associated with CIN and CC in a Han Chinese population; the findings indicated that the $\mathrm{T}$ allele confers a higher risk of developing CIN and CC [23]. The association of the SNP rs4636297 with CC might due to that this SNP is related to Drosha's recognition and cleavage of pri-miRNA [24]. In addition, Zhang et al. in 2018 reported that SNP rs1292037 is associated with the chemoresistance to cisplatin plus paclitaxel and prognosis of patients with CC [25].. Therefore, SNPs in miRNAs may alter the expression of miRNAs or affect their interaction with target genes, and ultimately be associated with cancer susceptibility.

In the current study, we genotyped 10 SNPs (rs1292037, rs13137 in miR-21; rs2227255, rs2227258 in miR-26b; rs2858061, rs34678647, rs2858060, rs2745709 in $m i R-221 / 222$; rs2297537, rs2297538 in $m i R-126)$ in healthy control, CIN and CC groups to investigate associations with CIN and CC in a Han Chinese population.

\section{Material and methods \\ Ethics statement}

The current study obtained the approval of the Institutional Review Board of the No. 3 Affiliated Hospital of Kunming Medical University. The protocol used by this investigation was in accordance with the principles expressed in the Helsinki Declaration of 1975, which was revised in 2008. Written informed consent was obtained from each participant.

\section{Subjects and clinical information}

In total, 435 patients with CIN and 743 with CC were enrolled in the current study. The patients were diagnosed with CIN and CC according to "Diagnosis and Treatment: Obstetrics and Gynaecology" and International Federation of Gynaecology and Obstetrics (FIGO 2009) at the Third Affiliated Hospital of Kunming Medical University from July 2018 to May 2020. Patients with other malignancies, a tumour therapy history and 
other chronic diseases were excluded. During the same period, 998 healthy women were recruited among those seeking health checkups in the same hospital and enrolled as the healthy control group.

\section{SNP selection and genotyping}

Previous studies have demonstrated that $m i R-21, m i R-$ $26 b$, $m i R-221 / 222$ and $m i R-126$ are associated with $C C$ development [11-16]. We therefore performed a preliminary survival analysis via a RNA interactomes database (ENCORI, http://starbase.sysu.edu.cn/index.php) [26], and found the expressions of these miRNA were associated with the survival rate of cervical cancer. Thus, in the current study, 10 SNPs (rs1292037, rs13137 in miR21; rs2227255, rs2227258 in $m i R-26 b$; rs2858061, rs34678647, rs2858060, rs2745709 in $m i R-221 / 222$; rs2297537, rs2297538 in $m i R-126)$ located $2 \mathrm{~kb}$ up or downstream of $m i R-21, m i R-26 b, m i R-221 / 222$, and $m i R-126$ were selected and the association of these SNPs with susceptibility of CIN and CC was analysed.

Genomic DNA was obtained from EDTA anticoagulated whole blood of the subjects using QIAamp Blood Mini Kit (Qiagen NV, Venlo, the Netherlands). The probes and primers used for genotyping were all purchased from ABI (http://www.appliedbiosystems. com). The 10 SNPs were genotyped using the TaqMan fluorescent quantitative PCR method with the QuantStudio $^{\text {тM }}$ Real-Time PCR instrument. The total PCR volume was $5 \mu \mathrm{L}$, and the reaction conditions were $95^{\circ} \mathrm{C}$ predenaturation for $10 \mathrm{~min}, 40$ cycles of $95^{\circ} \mathrm{C}$ denaturation for $15 \mathrm{~s}, 60^{\circ} \mathrm{C}$ annealing for $1 \mathrm{~min}$, and finally $60^{\circ} \mathrm{C}$ extension for $5 \mathrm{~min}$. Deionized water was used to replace template DNA as a negative control. The data were analysed by TaqMan Genotyper Software (Version 1.3.1). To identify the accuracy of SNP genotyping using the TaqMan assay, samples with each genotype of the 10 SNPs were sequenced.

\section{Statistical analysis}

Statistical analysis was performed using Microsoft Excel software and the SPSS 19.0 statistical package. The Hardy-Weinberg equilibrium (HWE) of the control group was evaluated to assess the representativeness of the study population, and significance threshold was set at $P<0.05$. Differences in age among the CIN, CC and control groups were compared using one-way ANOVA with the LSD test for multiple comparison correction. Different distributions of the SNP and miRNA alleles in the CIN, CC and control groups were compared using the chi-square test, and odds ratios (ORs) with associated $95 \%$ confidence intervals (CIs) were calculated. The association of the genotypes of these SNPs with CIN and $\mathrm{CC}$ was examined using inheritance model analysis in SNPstats software [27]. Five inheritance models (codominant, dominant, recessive, overdominant and log-additive) were analysed, and the best fit inheritance model of each SNP was determined based on AIC and $\mathrm{BIC}$ values. The inheritance model with the lowest AIC and $\mathrm{BIC}$ value was considered the best fit inheritance model. Bonferroni correction was performed for multiple comparisons, and the significance threshold was set at $P<0.005(0.05 / 10)$.

\section{Results}

\section{Clinical characteristic of subjects}

A total of 2176 subjects were enrolled in the current study. The general characteristics of the subjects are presented in Table 1. The ages of the subjects showed no significant difference among the control, CIN and CC groups $(P=0.172)$. Among the 743 patients with $C C$, 128 had adenocarcinoma, 609 squamous cell carcinoma, and 6 adenocarcinoma and squamous cell carcinoma.

\section{Association of SNPs in the miR-21, miR-26b, miR-221/222 and miR-126 genes with control, CIN and CC}

There are nine SNPs in the $m i R-21, m i R-26 b, m i R-221 /$ 222 and $m i R-126$ genes were found in HWE in the control group, except for rs2297538 in miR-126 $(P=0.026)$. The allelic and genotypic distributions of these 10 SNPs among the control, CIN and CC groups are presented in Table 2.

The genotype distributions of rs1292037 and rs13137 in $m i R-21$, rs2745709 in $m i R-221 / 222$ and rs2297537 and rs2297538 in miR-126 differed between the CIN and $C C$ groups $(P<0.05)$. However, only rs2297538 in $m i R$ 126 showed a difference after Bonferroni correction $(P=$ $0.001)$. In addition, the allele distribution of rs2297537

Table 1 The characteristics of the subjects enrolled in the current study

\begin{tabular}{lllll}
\hline & Control & CIN & Cervical Cancer & $P$ value \\
\hline $\mathrm{N}$ & 998 & 435 & 743 & \\
Ages & $48.05 \pm 10.69$ & $47.11 \pm 11.47$ & $47.25 \pm 9.97$ & 0.172 \\
CIN1 & 74 & & \\
CIN2 & 47 & & \\
CIN3 & 314 & & \\
Histological types & & & \\
SCC & & 609 & \\
AC & & 128 & \\
Others & & 6 & \\
Clinical stages & & & \\
I & & 228 & \\
II & & 3 & \\
III & & 248 \\
IV & & & \\
\hline
\end{tabular}


Table 2 The allele and genotype distribution of the SNPs in control, CIN and cervical cancer groups

\begin{tabular}{|c|c|c|c|c|c|c|c|c|c|c|}
\hline \multirow[t]{2}{*}{ SNPs } & \multirow{2}{*}{$\begin{array}{l}\text { Alleles/ } \\
\text { Genotypes }\end{array}$} & \multirow{2}{*}{$\begin{array}{l}\text { Control } \\
(n=998) \\
n(\%)\end{array}$} & \multirow{2}{*}{$\begin{array}{l}\text { CIN } \\
(n=435) \\
n(\%)\end{array}$} & \multirow{2}{*}{$\begin{array}{l}\text { CC } \\
(n=743) \\
n(\%)\end{array}$} & \multicolumn{2}{|c|}{ CIN vs Control } & \multicolumn{2}{|c|}{ CC vs Control } & \multicolumn{2}{|c|}{ CC vs CIN } \\
\hline & & & & & $P$ value & OR(95\%Cl) & $P$ value & OR(95\%Cl) & $P$ value & $\mathrm{OR}(95 \% \mathrm{Cl})$ \\
\hline \multirow[t]{5}{*}{ rs1292037 } & $\mathrm{T}$ & $1123(56.3)$ & $513(59.0)$ & $875(58.9)$ & 0.179 & 0.90 [0.76-1.05] & 0.122 & $0.90[0.78-1.43]$ & 0.969 & $1.00[0.85-1.19]$ \\
\hline & C & $873(43.7)$ & $357(41.0)$ & $611(41.1)$ & & & & & & \\
\hline & $\mathrm{T} / \mathrm{T}$ & 329 (33.0) & $138(31.7)$ & $268(36.1)$ & 0.004 & & 0.320 & & 0.010 & \\
\hline & $\mathrm{T} / \mathrm{C}$ & 465 (46.6) & $237(54.5)$ & $339(45.6)$ & & & & & & \\
\hline & $\mathrm{C} / \mathrm{C}$ & $204(20.4)$ & $60(13.8)$ & $136(18.3)$ & & & & & & \\
\hline \multirow[t]{5}{*}{ rs13137 } & A & $1121(56.2)$ & $512(58.9)$ & $874(58.8)$ & 0.181 & $1.12[0.95-1.31]$ & 0.117 & $1.11[0.97-1.28]$ & 0.987 & $1.00[0.84-1.18]$ \\
\hline & $\mathrm{T}$ & 875 (43.8) & $358(41.1)$ & $612(41.2)$ & & & & & & \\
\hline & $\mathrm{A} / \mathrm{A}$ & 327 (32.8) & $138(31.7)$ & $268(36.1)$ & 0.006 & & 0.303 & & 0.011 & \\
\hline & $A / T$ & $467(46.8)$ & $236(54.3)$ & $338(45.5)$ & & & & & & \\
\hline & $\mathrm{T} / \mathrm{T}$ & $204(20.4)$ & $61(14.0)$ & $137(18.4)$ & & & & & & \\
\hline \multirow[t]{5}{*}{ rs2858061 } & G & $1578(79.1)$ & $691(79.4)$ & 1149 (77.3) & 0.824 & $0.98[0.80-1.19]$ & 0.219 & $1.11[0.94-1.30]$ & 0.233 & 1.13 [0.92-1.39] \\
\hline & $C$ & $418(20.9)$ & $179(20.6)$ & $337(22.7)$ & & & & & & \\
\hline & $\mathrm{G} / \mathrm{G}$ & $628(62.9)$ & $271(62.3)$ & $450(60.6)$ & 0.436 & & 0.453 & & 0.171 & \\
\hline & $\mathrm{G} / \mathrm{C}$ & $322(32.3)$ & $149(34.3)$ & $249(33.5)$ & & & & & & \\
\hline & $\mathrm{C} / \mathrm{C}$ & $48(4.8)$ & $15(3.4)$ & $44(5.9)$ & & & & & & \\
\hline \multirow[t]{5}{*}{ rs34678647 } & G & 1615 (80.9) & $684(78.6)$ & $1207(81.2)$ & 0.157 & $0.87[0.71-1.06]$ & 0.816 & $1.02[0.86-1.21]$ & 0.125 & 1.18 [0.96-1.45] \\
\hline & $\mathrm{T}$ & 381 (19.1) & $186(21.4)$ & $279(18.8)$ & & & & & & \\
\hline & $\mathrm{G} / \mathrm{G}$ & $662(66.3)$ & $263(60.5)$ & $490(65.9)$ & 0.020 & & 0.509 & & 0.125 & \\
\hline & $\mathrm{G} / \mathrm{T}$ & $291(29.2)$ & $158(36.3)$ & 227 (30.6) & & & & & & \\
\hline & $\mathrm{T} / \mathrm{T}$ & $45(4.5)$ & $14(3.2)$ & $26(3.5)$ & & & & & & \\
\hline \multirow[t]{5}{*}{ rs2858060 } & $C$ & $1600(80.2)$ & $695(79.9)$ & $1162(78.2)$ & 0.865 & 0.98 [0.81-1.99] & 0.157 & 0.89 [0.75-1.05] & 0.333 & $0.90[0.73-1.11]$ \\
\hline & G & $396(19.8)$ & $175(20.1)$ & $324(21.8)$ & & & & & & \\
\hline & $\mathrm{C} / \mathrm{C}$ & $642(64.3)$ & $274(63.0)$ & $455(61.2)$ & 0.603 & & 0.369 & & 0.397 & \\
\hline & $C / G$ & $316(31.7)$ & 147 (33.8) & $252(33.9)$ & & & & & & \\
\hline & $\mathrm{G} / \mathrm{G}$ & $40(4.0)$ & $14(3.2)$ & $36(4.8)$ & & & & & & \\
\hline \multirow[t]{5}{*}{ rs 2745709} & $C$ & 1229 (61.6) & $507(58.3)$ & $878(59.1)$ & 0.097 & $0.87[0.74-1.03]$ & 0.137 & 0.90 [0.79-1.03] & 0.7 & $1.03[0.87-1.22]$ \\
\hline & $\mathrm{T}$ & 767 (38.4) & $363(41.7)$ & $608(40.9)$ & & & & & & \\
\hline & $\mathrm{C} / \mathrm{C}$ & $381(38.2)$ & $129(29.7)$ & $260(35.0)$ & 0.001 & & 0.331 & & 0.010 & \\
\hline & $C / T$ & $467(46.8)$ & $249(57.2)$ & $358(48.2)$ & & & & & & \\
\hline & $\mathrm{T} / \mathrm{T}$ & $150(15.0)$ & $57(13.1)$ & $125(16.8)$ & & & & & & \\
\hline \multirow[t]{5}{*}{ rs2297537 } & $C$ & $1618(81.1)$ & $729(83.8)$ & 1172 (78.9) & 0.081 & 1.21 [0.98-1.49] & 0.109 & $0.87[0.74-1.03]$ & 0.003 & $0.72[0.58-0.90]$ \\
\hline & G & $378(18.9)$ & $141(16.2)$ & $314(21.1)$ & & & & & & \\
\hline & $\mathrm{C} / \mathrm{C}$ & $659(66.0)$ & $302(69.4)$ & $459(61.8)$ & 0.098 & & 0.174 & & 0.010 & \\
\hline & $C / G$ & $300(30.1)$ & $125(28.7)$ & $254(34.2)$ & & & & & & \\
\hline & $\mathrm{G} / \mathrm{G}$ & $39(3.9)$ & $8(1.8)$ & $30(4.0)$ & & & & & & \\
\hline \multirow[t]{5}{*}{ rs2297538 } & G & $1705(85.4)$ & $723(83.1)$ & $1261(84.9)$ & 0.113 & $1.19[0.96-1.48]$ & 0.644 & $1.05[0.87-1.26]$ & 0.259 & $0.88[0.70-1.10]$ \\
\hline & $A$ & 291 (14.6) & $147(16.9)$ & $225(15.1)$ & & & & & & \\
\hline & $\mathrm{G} / \mathrm{G}$ & 737 (73.8) & $315(72.4)$ & $535(72.0)$ & 0.016 & & 0.339 & & 0.001 & \\
\hline & $\mathrm{G} / \mathrm{A}$ & 231 (23.1) & $93(21.4)$ & $191(25.7)$ & & & & & & \\
\hline & $A / A$ & $30(3.0)$ & $27(6.2)$ & $17(2.3)$ & & & & & & \\
\hline \multirow[t]{2}{*}{ rs2227255 } & $\mathrm{T}$ & $1376(68.9)$ & $600(69.0)$ & 1005 (67.6) & 0.988 & $1.00[0.84-1.19]$ & 0.412 & $1.06[0.92-1.23]$ & 0.502 & 1.06 [0.89-1.28] \\
\hline & $C$ & $620(31.1)$ & $270(31.0)$ & $481(32.4)$ & & & & & & \\
\hline
\end{tabular}


Table 2 The allele and genotype distribution of the SNPs in control, CIN and cervical cancer groups (Continued)

\begin{tabular}{|c|c|c|c|c|c|c|c|c|c|c|}
\hline \multirow[t]{2}{*}{ SNPs } & \multirow{2}{*}{$\begin{array}{l}\text { Alleles/ } \\
\text { Genotypes }\end{array}$} & \multirow{2}{*}{$\begin{array}{l}\text { Control } \\
(n=998) \\
\mathrm{n}(\%)\end{array}$} & \multirow{2}{*}{$\begin{array}{l}\text { CIN } \\
(n=435) \\
n(\%)\end{array}$} & \multirow{2}{*}{$\begin{array}{l}\text { CC } \\
(n=743) \\
n(\%)\end{array}$} & \multicolumn{2}{|c|}{ CIN vs Control } & \multicolumn{2}{|c|}{ CC vs Control } & \multicolumn{2}{|c|}{ CC vs CIN } \\
\hline & & & & & $P$ value & $\mathrm{OR}(95 \% \mathrm{Cl})$ & $P$ value & $\mathrm{OR}(95 \% \mathrm{Cl})$ & $P$ value & OR(95\%Cl) \\
\hline & $T / T$ & $474(47.5)$ & $205(47.1)$ & $350(47.1)$ & 0.946 & & 0.309 & & 0.329 & \\
\hline & $\mathrm{T} / \mathrm{C}$ & $428(42.9)$ & $190(43.7)$ & $305(41.0)$ & & & & & & \\
\hline & $\mathrm{C} / \mathrm{C}$ & $96(9.6)$ & $40(9.2)$ & 88 (11.8) & & & & & & \\
\hline \multirow[t]{5}{*}{ rs 2227258} & G & 1387 (69.5) & $604(69.4)$ & $1002(67.4)$ & 0.973 & 1.00 [0.84-1.19] & 0.195 & $1.10[0.95-1.27]$ & 0.316 & 1.10 [0.92-1.31] \\
\hline & A & $609(30.5)$ & $266(30.6)$ & $484(32.6)$ & & & & & & \\
\hline & $\mathrm{G} / \mathrm{G}$ & $481(48.2)$ & 207 (47.6) & $349(47.0)$ & 0.911 & & 0.147 & & 0.183 & \\
\hline & $\mathrm{G} / \mathrm{A}$ & $425(42.6)$ & $190(43.7)$ & $304(40.9)$ & & & & & & \\
\hline & $A / A$ & $92(9.2)$ & $38(8.7)$ & $90(12.1)$ & & & & & & \\
\hline
\end{tabular}

in $\operatorname{miR}-126$ was significantly different $(P=0.003)$, and the $\mathrm{C}$ allele might be associated with a decreased risk of CC $(\mathrm{OR}=0.72$, 95\% CI: 0.58-0.90). In addition, the genotype distributions of rs1292037 and rs13137 in $m i R$ 21 and rs2745709 in $m i R-221 / 222$ showed differences between the CIN and control groups $(P<0.05)$. Nevertheless, only rs1292037 in $m i R-21$ and rs2745709 in $m i R-221 / 222$ remained significantly differences after Bonferroni correction $(P=0.004$ and $P=0.001)$. No difference in the distribution of these SNPs was found by comparing the control and CC groups $(P>0.005)$.

Inheritance analysis of SNPs in the miR-21, miR-26b, miR221/222 and miR-126 genes with control, CIN and CC

The association of the genotypes of the 10 SNPs with control and CIN was evaluated using inheritance model analysis (Table 3 ). In $m i R-21$, a significant difference in rs1292037 and rs13137 was observed in the recessive model $(P=0.002$ and 0.003$)$. Moreover, $\mathrm{T} / \mathrm{T}-\mathrm{T} / \mathrm{C}$ genotype in rs1292037 and A/A-A/T genotype in rs13137 might be associated with an increased risk of CIN (OR = 1.61, 95\% CI: $1.17-2.20$ and $\mathrm{OR}=1.58,95 \% \mathrm{CI}: 1.15-$ 2.15). In addition, rs2745709 in $m i R-221 / 222$ was significantly different $(P<0.001)$, and $\mathrm{C} / \mathrm{C}-\mathrm{T} / \mathrm{T}$ genotype might be associated with a decreased risk of CIN in the overdominant model (OR $=0.66,95 \% \mathrm{CI}$ : 0.52-0.82).

The association of the genotypes of the 10 SNPs with CIN and CC was evaluated using inheritance model analysis (Table 4). In $m i R-21$, our results revealed a significant difference in $\operatorname{rs} 1292037(P=0.003)$ between these two groups, and the T/T-C/C genotype might be associated with an increased risk of $\mathrm{CC}$ in the overdominant model $(\mathrm{OR}=1.43,95 \% \mathrm{CI}: 1.12-1.81)$. The rs13137 also showed a significant difference $(P=0.004)$, and the A/A$\mathrm{T} / \mathrm{T}$ genotype might be associated with an increased risk of $\mathrm{CC}$ in the overdominant model $(\mathrm{OR}=1.42,95 \% \mathrm{CI}$ : 1.12-1.80). In $m i R-221 / 222$, the rs2745709 exhibited a significant difference $(P=0.003)$, and the $\mathrm{T} / \mathrm{T}-\mathrm{C} / \mathrm{C}$ genotype might be associated with an increased risk of $\mathrm{CC}$ in the overdominant model $(\mathrm{OR}=1.44,95 \% \mathrm{CI}$ : $1.13-1.83)$. In $m i R-126$, rs2297537 and rs2297538 showed significant differences in the log-additive and recessive models, respectively $(P=0.003$ and 0.001$)$, and $2 C / C+C / G$ in rs2297537 and G/G-A/G in rs2297538 genotype might be associated with an increased risk of $\mathrm{CC}(\mathrm{OR}=0.71$, 95\% CI: $0.57-0.89$ and OR $=2.83$, 95\% CI: $1.52-5.25)$. In contrast, no significant difference in the 10 SNPs between the CIN and control groups were detected (data not shown).

\section{Discussion}

Many studies have reported that SNPs in miRNAs are related to various diseases, especially cancers [22, 23, 28, $29]$. In the current study, we investigated the association of 10 SNPs in the $m i R-21, m i R-26 b, m i R-221 / 222$ and miR-126 genes with $\mathrm{CIN}$ and $\mathrm{CC}$ in Han Chinese women. According to our results, rs2297538 and rs2297537 in $m i R-126$, rs1292037 in $m i R-21$, and rs2745709 in $m i R-221 / 222$ are associated with CIN or $\mathrm{CC}$ susceptibility in the Han Chinese population.

miR-21 acts as an oncogene in cancer by regulating signalling pathways involved in cancer development [30]. In 2015, Xu et al. reported that overexpression of miR21 inhibited expression of the target gene PTEN in CC cell lines, and promoted the proliferation, migration and invasion of CC cells [31]. In the current study, we found a significant difference in rs1292037 and rs13137 in miR-21 between CIN and CC groups in the overdominant model $(P=0.003$ and 0.004$)$. Moreover, we observed a significant difference in rs1292037 and rs13137 in $m i R-21$ between CIN and control groups in the recessive model ( $P=0.002$ and 0.003$)$. In 2018, Zhang et al. investigated correlations of $m i R-21$ gene rs1292037 and rs13137 with chemosensitivity to cisplatin plus paclitaxel and prognosis before CC surgery [25], the results showed that rs1292037 is associated with chemoresistance to cisplatin plus paclitaxel as well as CC prognosis [25]. In 2017, Du et al. detected the sensitivity of CC 
Table 3 The inheritance model analysis of the ten SNPs in miRNA genes among Control and CIN groups

\begin{tabular}{|c|c|c|c|c|c|c|c|c|}
\hline SNPs & Models & Genotypes & $\begin{array}{l}\text { CIN } \\
\text { n (\%) }\end{array}$ & $\begin{array}{l}\text { CON } \\
\text { n (\%) }\end{array}$ & OR $(95 \% \mathrm{CI})$ & $P$ value & AIC & $\mathrm{BIC}$ \\
\hline \multirow[t]{10}{*}{ rs1292037 } & Codominant & $\mathrm{T} / \mathrm{T}$ & $138(31.7)$ & $329(33.0)$ & 1.00 & 0.003 & 1753.7 & 1769.5 \\
\hline & & $\mathrm{T} / \mathrm{C}$ & $237(54.5)$ & $465(46.6)$ & $0.82(0.64-1.06)$ & & & \\
\hline & & $\mathrm{C} / \mathrm{C}$ & 60 (13.8) & $204(20.4)$ & $1.43(1.01-2.02)$ & & & \\
\hline & Dominant & $\mathrm{T} / \mathrm{T}$ & $138(31.7)$ & $329(33.0)$ & 1.00 & 0.640 & 1763.1 & 1773.6 \\
\hline & & $\mathrm{T} / \mathrm{C}-\mathrm{C} / \mathrm{C}$ & $297(68.3)$ & $669(67.0)$ & $0.94(0.74-1.20)$ & & & \\
\hline & Recessive & T/T-T/C & $375(86.2)$ & 794 (79.6) & 1.00 & 0.002 & 1754.0 & 1764.5 \\
\hline & & $\mathrm{C} / \mathrm{C}$ & $60(13.8)$ & $204(20.4)$ & $1.61(1.17-2.20)$ & & & \\
\hline & Overdominant & T/T-C/C & $198(45.5)$ & $533(53.4)$ & 1.00 & 0.006 & 1755.7 & 1766.3 \\
\hline & & $\mathrm{T} / \mathrm{C}$ & $237(54.5)$ & $465(46.6)$ & $0.73(0.58-0.91)$ & & & \\
\hline & Log-additive & - & - & - & $1.12(0.95-1.31)$ & 0.180 & 1761.5 & 1772.0 \\
\hline \multirow[t]{10}{*}{ rs13137 } & Codominant & $\mathrm{A} / \mathrm{A}$ & $138(31.7)$ & $327(32.8)$ & 1.00 & 0.005 & 1754.7 & 1770.5 \\
\hline & & $\mathrm{A} / \mathrm{T}$ & $236(54.2)$ & $467(46.8)$ & $0.84(0.65-1.08)$ & & & \\
\hline & & $\mathrm{T} / \mathrm{T}$ & $61(14.0)$ & $204(20.4)$ & $1.41(1.00-2.00)$ & & & \\
\hline & Dominant & $\mathrm{A} / \mathrm{A}$ & $138(31.7)$ & 327 (32.8) & 1.00 & 0.700 & 1763.1 & 1773.7 \\
\hline & & $\mathrm{A} / \mathrm{T}-\mathrm{T} / \mathrm{T}$ & $297(68.3)$ & $671(67.2)$ & $0.95(0.75-1.21)$ & & & \\
\hline & Recessive & $\mathrm{A} / \mathrm{A}-\mathrm{A} / \mathrm{T}$ & $374(86.0)$ & 794 (79.6) & 1.00 & 0.003 & 1754.7 & 1765.2 \\
\hline & & $\mathrm{T} / \mathrm{T}$ & $61(14.0)$ & $204(20.4)$ & $1.58(1.15-2.15)$ & & & \\
\hline & Overdominant & $\mathrm{A} / \mathrm{A}-\mathrm{T} / \mathrm{T}$ & $199(45.8)$ & $531(53.2)$ & 1.00 & 0.009 & 1756.5 & 1767.1 \\
\hline & & $A / T$ & $236(54.2)$ & $467(46.8)$ & $0.74(0.59-0.93)$ & & & \\
\hline & Log-additive & - & - & - & $1.12(0.95-1.31)$ & 0.180 & 1761.5 & 1772.0 \\
\hline \multirow[t]{10}{*}{ rs2745709 } & Codominant & $\mathrm{C} / \mathrm{C}$ & $129(29.7)$ & $381(38.2)$ & 1.00 & 0.001 & 1751.6 & 1767.5 \\
\hline & & $C / T$ & $249(57.2)$ & $467(46.8)$ & $0.64(0.49-0.82)$ & & & \\
\hline & & $\mathrm{T} / \mathrm{T}$ & $57(13.1)$ & $150(15.0)$ & $0.89(0.62-1.28)$ & & & \\
\hline & Dominant & $\mathrm{C} / \mathrm{C}$ & $129(29.7)$ & 381 (38.2) & 1.00 & 0.002 & 1753.5 & 1764.1 \\
\hline & & $\mathrm{C} / \mathrm{T}-\mathrm{T} / \mathrm{T}$ & $306(70.3)$ & $617(61.8)$ & $0.68(0.54-0.87)$ & & & \\
\hline & Recessive & $\mathrm{C} / \mathrm{C}-\mathrm{C} / \mathrm{T}$ & 378 (86.9) & $848(85.0)$ & 1.00 & 0.340 & 1762.4 & 1772.9 \\
\hline & & $\mathrm{T} / \mathrm{T}$ & $57(13.1)$ & $150(15.0)$ & $1.17(0.84-1.63)$ & & & \\
\hline & Overdominant & $\mathrm{C} / \mathrm{C}-\mathrm{T} / \mathrm{T}$ & $186(42.8)$ & $531(53.2)$ & 1.00 & $<0.001$ & 1750.0 & 1760.6 \\
\hline & & $C / T$ & $249(57.2)$ & $467(46.8)$ & $0.66(0.52-0.82)$ & & & \\
\hline & Log-additive & - & - & - & $0.87(0.73-1.02)$ & 0.090 & 1760.4 & 1770.9 \\
\hline
\end{tabular}

cells to paclitaxel and found that inhibiting expression of miR-21 could suppress cell proliferation and colony formation via PTEN/AKT pathway regulation, therefore improving the PTX sensitivity of CC cells [32]. Thus, rs1292037 might play an important role in the association of miR-21 with the development of CIN or CC, in addition to the chemosensitivity of CC. Moreover, in 2015. Chacon-Cortes et al. performed an association study to assess correlation between rs1292037 and rs13137 in the miR-21 gene and breast cancer, unfortunately, no association was detected [33]. The reason for the discrepancy between the study of Chacon-Cortes et al. and the current study might due to different types of cancers examined. These two SNPs should be investigated in other cancer types, such as lung cancer.
Consequently, the function of these two SNPs in the development of $\mathrm{CC}$ should be investigated in future studies.

Several studies have found that miR-126 is usually under expressed in human colorectal cancer [34], breast cancer [35] and CC [18]. Additionally, our previous study found that rs4636297 in miR-126 was associated with CIN and CC in a Han Chinese population [23]. In the current study, we found that the distribution of the miR-126 rs2297538 genotypes and rs2297537 alleles were significantly different between CIN and CC groups, which indicated that these two SNPs might play important roles in the progression of CIN to CC. The rs2297537 and rs2297538 are located in the promoter region, and are only 194 base pairs away. The former 
Table 4 The inheritance model analysis of the ten SNPs in miRNA genes among CIN and Cervical cancer groups

\begin{tabular}{|c|c|c|c|c|c|c|c|c|}
\hline SNPs & Models & Genotypes & $\mathrm{CC}$ & CIN & OR (95 Cl) & $P$ value & AIC & $\mathrm{BIC}$ \\
\hline \multirow[t]{10}{*}{ rs1292037 } & \multirow[t]{3}{*}{ Codominant } & $\mathrm{T} / \mathrm{T}$ & $268(36.1)$ & $138(31.7)$ & 1.00 & \multirow[t]{3}{*}{0.010} & \multirow[t]{3}{*}{1548.3} & \multirow[t]{3}{*}{1563.5} \\
\hline & & $\mathrm{T} / \mathrm{C}$ & 339 (45.6) & $237(54.5)$ & $1.36(1.04-1.77)$ & & & \\
\hline & & $\mathrm{C} / \mathrm{C}$ & $136(18.3)$ & $60(13.8)$ & $0.86(0.59-1.24)$ & & & \\
\hline & \multirow[t]{2}{*}{ Dominant } & $\mathrm{T} / \mathrm{T}$ & $268(36.1)$ & 138 (31.7) & 1.00 & \multirow[t]{2}{*}{0.130} & \multirow[t]{2}{*}{1553.3} & \multirow[t]{2}{*}{1563.4} \\
\hline & & T/C-C/C & 475 (63.9) & $297(68.3)$ & $1.21(0.94-1.56)$ & & & \\
\hline & \multirow[t]{2}{*}{ Recessive } & T/T-T/C & $607(81.7)$ & 375 (86.2) & 1.00 & \multirow[t]{2}{*}{0.042} & \multirow[t]{2}{*}{1551.5} & \multirow[t]{2}{*}{1561.6} \\
\hline & & $\mathrm{C} / \mathrm{C}$ & $136(18.3)$ & $60(13.8)$ & $0.71(0.51-0.99)$ & & & \\
\hline & \multirow[t]{2}{*}{ Overdominant } & $\mathrm{T} / \mathrm{T}-\mathrm{C} / \mathrm{C}$ & $404(54.4)$ & $198(45.5)$ & 1.00 & \multirow[t]{2}{*}{0.003} & \multirow[t]{2}{*}{1547.0} & \multirow[t]{2}{*}{1557.1} \\
\hline & & $\mathrm{T} / \mathrm{C}$ & 339 (45.6) & $237(54.5)$ & $1.43(1.12-1.81)$ & & & \\
\hline & Log-additive & - & - & - & $1.00(0.84-1.18)$ & 0.970 & 1555.6 & 1565.7 \\
\hline \multirow[t]{10}{*}{ rs13137 } & \multirow[t]{3}{*}{ Codominant } & $\mathrm{A} / \mathrm{A}$ & $268(36.1)$ & $138(31.7)$ & 1.00 & \multirow[t]{3}{*}{0.011} & \multirow[t]{3}{*}{1548.5} & \multirow[t]{3}{*}{1563.7} \\
\hline & & $\mathrm{A} / \mathrm{T}$ & $338(45.5)$ & $236(54.2)$ & $1.36(1.04-1.77)$ & & & \\
\hline & & $\mathrm{T} / \mathrm{T}$ & $137(18.4)$ & $61(14)$ & $0.86(0.60-1.25)$ & & & \\
\hline & Dominant & $\mathrm{A} / \mathrm{A}$ & $268(36.1)$ & 138 (31.7) & 1.00 & 0.130 & 1553.3 & 1563.4 \\
\hline & & A/T-T/T & $475(63.9)$ & $297(68.3)$ & $1.21(0.94-1.56)$ & & & \\
\hline & Recessive & $\mathrm{A} / \mathrm{A}-\mathrm{A} / \mathrm{T}$ & 606 (81.6) & $374(86)$ & 1.00 & 0.048 & 1551.7 & 1561.8 \\
\hline & & $\mathrm{T} / \mathrm{T}$ & 137 (18.4) & $61(14)$ & $0.72(0.52-1.00)$ & & & \\
\hline & Overdominant & A/A-T/T & $405(54.5)$ & 199 (45.8) & 1.00 & 0.004 & 1547.1 & 1557.3 \\
\hline & & $\mathrm{A} / \mathrm{T}$ & $338(45.5)$ & $236(54.2)$ & $1.42(1.12-1.80)$ & & & \\
\hline & Log-additive & - & - & - & $1.00(0.84-1.18)$ & 0.990 & 1555.6 & 1565.7 \\
\hline rs2745709 & Codominant & $\mathrm{C} / \mathrm{C}$ & $260(35)$ & 129 (29.7) & 1.00 & 0.010 & 1548.4 & 1563.6 \\
\hline & & $C / T$ & $358(48.2)$ & $249(57.2)$ & $1.40(1.07-1.83)$ & & & \\
\hline & & $\mathrm{T} / \mathrm{T}$ & 125 (16.8) & $57(13.1)$ & $0.92(0.63-1.34)$ & & & \\
\hline & Dominant & $\mathrm{C} / \mathrm{C}$ & $260(35)$ & $129(29.7)$ & 1.00 & 0.059 & 1552.0 & 1562.2 \\
\hline & & $\mathrm{C} / \mathrm{T}-\mathrm{T} / \mathrm{T}$ & $483(65)$ & $306(70.3)$ & $1.28(0.99-1.65)$ & & & \\
\hline & Recessive & $\mathrm{C} / \mathrm{C}-\mathrm{C} / \mathrm{T}$ & $618(83.2)$ & $378(86.9)$ & 1.00 & 0.085 & 1552.6 & 1562.8 \\
\hline & & $\mathrm{T} / \mathrm{T}$ & 125 (16.8) & $57(13.1)$ & $0.75(0.53-1.05)$ & & & \\
\hline & Overdominant & $\mathrm{C} / \mathrm{C}-\mathrm{T} / \mathrm{T}$ & $385(51.8)$ & $186(42.8)$ & 1.00 & 0.003 & 1546.5 & 1556.7 \\
\hline & & $\mathrm{C} / \mathrm{T}$ & $358(48.2)$ & $249(57.2)$ & $1.44(1.13-1.83)$ & & & \\
\hline & Log-additive & - & - & - & $1.04(0.87-1.24)$ & 0.690 & 1555.4 & 1565.6 \\
\hline rs2297537 & Codominant & $\mathrm{C} / \mathrm{C}$ & 459 (61.8) & 302 (69.4) & 1.00 & 0.009 & 1548.1 & 1563.3 \\
\hline & & $\mathrm{C} / \mathrm{G}$ & $254(34.2)$ & $125(28.7)$ & $0.75(0.58-0.97)$ & & & \\
\hline & & $\mathrm{G} / \mathrm{G}$ & $30(4)$ & $8(1.8)$ & $0.41(0.18-0.90)$ & & & \\
\hline & Dominant & $\mathrm{C} / \mathrm{C}$ & $459(61.8)$ & $302(69.4)$ & 1.00 & 0.008 & 1548.5 & 1558.6 \\
\hline & & $\mathrm{C} / \mathrm{G}-\mathrm{G} / \mathrm{G}$ & $284(38.2)$ & 133 (30.6) & $0.71(0.55-0.92)$ & & & \\
\hline & Recessive & $\mathrm{C} / \mathrm{C}-\mathrm{C} / \mathrm{G}$ & $713(96)$ & 427 (98.2) & 1.00 & 0.032 & 1551.0 & 1561.1 \\
\hline & & $\mathrm{G} / \mathrm{G}$ & $30(4)$ & $8(1.8)$ & $0.45(0.20-0.98)$ & & & \\
\hline & Overdominant & $\mathrm{C} / \mathrm{C}-\mathrm{G} / \mathrm{G}$ & 489 (65.8) & $310(71.3)$ & 1.00 & 0.052 & 1551.8 & 1562.0 \\
\hline & & $\mathrm{C} / \mathrm{G}$ & $254(34.2)$ & $125(28.7)$ & $0.78(0.60-1.00)$ & & & \\
\hline & Log-additive & - & - & - & $0.71(0.57-0.89)$ & 0.003 & 1546.6 & 1556.7 \\
\hline rs2297538 & Codominant & $\mathrm{G} / \mathrm{G}$ & $535(72)$ & $315(72.4)$ & 1.00 & 0.002 & 1544.6 & 1559.9 \\
\hline & & $\mathrm{A} / \mathrm{G}$ & $191(25.7)$ & $93(21.4)$ & $0.83(0.62-1.10)$ & & & \\
\hline & & A/A & $17(2.3)$ & $27(6.2)$ & $2.70(1.45-5.03)$ & & & \\
\hline & Dominant & $\mathrm{G} / \mathrm{G}$ & $535(72)$ & $315(72.4)$ & 1.00 & 0.880 & 1555.6 & 1565.7 \\
\hline
\end{tabular}


Table 4 The inheritance model analysis of the ten SNPs in miRNA genes among CIN and Cervical cancer groups (Continued)

\begin{tabular}{|c|c|c|c|c|c|c|c|c|}
\hline SNPs & Models & Genotypes & $\mathrm{CC}$ & CIN & OR (95 Cl) & $P$ value & AIC & $\mathrm{BIC}$ \\
\hline & & A/G-A/A & $208(28)$ & $120(27.6)$ & $0.98(0.75-1.28)$ & & & \\
\hline & \multirow[t]{2}{*}{ Recessive } & $\mathrm{G} / \mathrm{G}-\mathrm{A} / \mathrm{G}$ & $726(97.7)$ & 408 (93.8) & 1.00 & 0.001 & 1544.4 & 1554.5 \\
\hline & & A/A & $17(2.3)$ & $27(6.2)$ & $2.83(1.52-5.25)$ & & & \\
\hline & \multirow[t]{2}{*}{ Overdominant } & $\mathrm{G} / \mathrm{G}-\mathrm{A} / \mathrm{A}$ & $552(74.3)$ & 342 (78.6) & 1.00 & 0.092 & 1552.7 & 1562.9 \\
\hline & & $A / G$ & $191(25.7)$ & $93(21.4)$ & $0.79(0.59-1.04)$ & & & \\
\hline & Log-additive & - & - & - & $1.13(0.91-1.40)$ & 0.280 & 1554.4 & 1564 \\
\hline
\end{tabular}

might serve as a binding site for transcription factors, as predicted by the NIH database [36]. Although the function of rs2297537 and rs2297538 is still unknown, our results indicated that they might be associated with $\mathrm{CIN}$ progression to $\mathrm{CC}$ through influencing transcription factors binding efficiency at the initiation of miR-126 transcription.

In 2013, Gocze et al. reported that miR-221 is overexpressed in squamous cell carcinoma, regardless of HPV status and clinical grade [16]. Similarly, miR-222 was reported to be up-regulated in CC tissues [13]. In the current study, we found a significant difference of rs2745709 in the miR-221/222 between the CIN and control groups $(P=0.001)$. Few studies have reported the association between rs2745709 and CC, with a lack of reports about the relationship between rs2745709 and expression of $m i R-221$. Thus, the role of rs2745709 in $\mathrm{CC}$ remains unclear, and its function in $\mathrm{CC}$ should be investigated.

In the current study, we investigated the association of SNPs in $m i R-21, m i R-26 b, m i R-221 / 222$, and $m i R-126$ among healthy controls, CIN patients and CC patients in a Han Chinese population. Our data showed that rs2297538 in miR-126, rs1292037 in $m i R-21$ and rs2745709 in $m i R-221 / 222$ are associated with the development of CIN and CC. In the future, larger-scale and functional SNP studies are required to better clarify and examine the role of these SNPs in the susceptibility, resistance and development of CC.

\section{Acknowledgements}

Our great gratitude was expressed to the participation of the patients and control subjects in current study.

\section{Authors' contributions}

LS and YFY designed the current study; JY, ZLY and YYW finished the main part of experiment and data analysis of the current study; JMX and RL finished the sample clinical diagnose and collection; CYL and SYL participated in the parts of the experiments; LS drafted the manuscript; YFY revised the manuscript. And all authors have read and approved the final manuscript.

\section{Funding}

This work was supported by grants from the Fundamental Research Funds for the Central Universities of Peking Union Medical College (3332019111), Special Funds for High-level Healthy Talents of Yunnan Province (L-201615 and H-2018014), Yunnan Province Clinical Research Center for Gynecological and Obstetric Disease, Yunnan Provincial Science and Technology
Department (2019HC0060). The funders had no role in study design, data collection and analysis, decision to publish or preparation of the manuscript.

\section{Availability of data and materials}

The data generated during the current study are available to any scientist wishing to use them for non-commercial purpose from the corresponding author on reasonable request. However, the clinical data might be available without the privacy data of participates in the current study.

\section{Declarations}

Ethics approval and consent to participate

The current study was approved by the Institutional Review Boards of the No. 3 Affiliated Hospitals of Kunming Medical University and was performed in accordan ce with the principles of the Declaration of Helsinki. All individuals enrolled in this study provided written informed consent.

\section{Consent for publication}

Not applicable.

\section{Competing interests}

The authors declare that they have no competing interests.

\section{Author details}

${ }^{1}$ Institute of Medical Biology, Chinese Academy of Medical Sciences \& Peking Union Medical College, Kunming 650118, Yunnan, China. ${ }^{2}$ Department of Gynaecologic Oncology, The 3rd Affiliated Hospital of Kunming Medical University, Kunming 650118, China. ${ }^{3}$ Department of Obstetrics and Gynaecologic, Kunming Yan'an Hospital, Kunming 650051, China. ${ }^{4}$ Yunnan Key Laboratory of Vaccine Research \& Development on Severe Infectious Disease, Kunming 650118, Yunnan, China.

Received: 25 April 2021 Accepted: 28 August 2021

Published online: 07 September 2021

References

1. Sung H, Ferlay J, Siegel RL, Laversanne M, Soerjomataram I, Jemal A, et al. Global cancer statistics 2020: GLOBOCAN estimates of incidence and mortality worldwide for 36 cancers in 185 countries. CA Cancer J Clin. 2021; (3):209-49. https://doi.org/10.3322/caac.21660.

2. Crow JM. HPV: the global burden. Nature. 2012;488(7413):S2-3. https://doi. org/10.1038/488S2a.

3. Siegler E, Shiner M, Segev Y, Mackuli L, Lahat N, Lavie O. Prevalence and genotype distribution of HPV types in women at risk for cervical neoplasia in Israel. IMAJ. 2017;19(10):635-9.

4. de Freitas AC, Gurgel AP, Chagas BS, Coimbra EC, do Amaral CM. Susceptibility to cervical cancer: an overview. Gynecol Oncol. 2012;126(2): 304-11. https://doi.org/10.1016/j.ygyno.2012.03.047.

5. Bartel DP. Metazoan MicroRNAs. Cell. 2018;173(1):20-51. https://doi.org/10.1 016/j.cell.2018.03.006.

6. Bushati N, Cohen SM. microRNA functions. Annu Rev Cell Dev Biol. 2007; 23(1):175-205. https://doi.org/10.1146/annurev.cellbio.23.090506.123406.

7. Iorio MV, Croce CM. MicroRNA dysregulation in cancer: diagnostics, monitoring and therapeutics. A comprehensive review. EMBO Mol Med. 2017:9(6):852.

8. Iorio MV, Croce CM. MicroRNA dysregulation in cancer: diagnostics, monitoring and therapeutics. A comprehensive review. EMBO Mol Med. 2012;4(3):143-59. https://doi.org/10.1002/emmm.201100209. 
9. Tornesello ML, Faraonio R, Buonaguro L, Annunziata C, Starita N, Cerasuolo A, et al. The role of microRNAs, long non-coding RNAs, and circular RNAs in cervical Cancer. Front Oncol. 2020;10:150. https://doi.org/10.3389/fonc.2020. 00150.

10. Laengsri V, Kerdpin U, Plabplueng C, Treeratanapiboon L, Nuchnoi P. Cervical Cancer markers: epigenetics and microRNAs. Lab Med. 2018;49(2): 97-111. https://doi.org/10.1093/labmed/Imx080.

11. Yuan $Y$, Min SJ, Xu DQ, Shen Y, Yan HY, Wang Y, et al. Expressions of VEGF and miR-21 in tumor tissues of cervical cancer patients with HPV infection and their relationships with prognosis. Eur Rev Med Pharmacol Sci. 2018; 22(19):6274-9. https://doi.org/10.26355/eurrev_201810_16035.

12. Luo M, Shen D, Wang W, Xian J. Aberrant expression of microRNA-26b and its prognostic potential in human cervical cancer. Int J Clin Exp Pathol. 2015;8(5):5542-8.

13. Sun $Y$, Zhang B, Cheng J, Wu Y, Xing F, Wang $Y$, et al. MicroRNA-222 promotes the proliferation and migration of cervical cancer cells. Clin Invest Med. 2014;37(3):E131. https://doi.org/10.25011/cim.v37i3.21380.

14. Srivastava SK, Ahmad A, Zubair H, Miree O, Singh S, Rocconi RP, et al. MicroRNAs in gynecological cancers: small molecules with big implications. Cancer Lett. 2017;407:123-38. https://doi.org/10.1016/j.canlet.2017.05.011.

15. Yu Q, Liu SL, Wang H, Shi G, Yang P, Chen XL. miR-126 suppresses the proliferation of cervical cancer cells and alters cell sensitivity to the chemotherapeutic drug bleomycin. Asian Pac J Cancer Prev. 2014;14(11): 6569-72. https://doi.org/10.7314/apjcp.2013.14.11.6569.

16. Gocze K, Gombos K, Juhasz K, Kovacs K, Kajtar B, Benczik M, et al. Unique microRNA expression profiles in cervical cancer. Anticancer Res. 2013;33(6): 2561-7.

17. Ebrahimi F, Gopalan V, Smith RA, Lam AK. miR-126 in human cancers: clinical roles and current perspectives. Exp Mol Pathol. 2014;96(1):98-107. https://doi.org/10.1016/j.yexmp.2013.12.004

18. Xu J, Wang H, Wang H, Chen Q, Zhang L, Song C, et al. The inhibition of miR-126 in cell migration and invasion of cervical cancer through regulating ZEB1. Hereditas. 2019;156(1):11. https://doi.org/10.1186/s41065-019-0087-7.

19. Abd El-Fattah AA, Sadik NAH, Shaker OG, Mohamed Kamal A. Single nucleotide polymorphism in SMAD7 and CHI3L1 and colorectal Cancer risk. Mediat Inflamm. 2018;2018:9853192-23. https://doi.org/10.1155/2018/98531 92.

20. Srivastava K, Srivastava A. Comprehensive review of genetic association studies and meta-analyses on miRNA polymorphisms and cancer risk. PLoS One. 2012;7(11):e50966. https://doi.org/10.1371/journal.pone.0050966.

21. Link A, Kupcinskas J, Wex T, Malfertheiner P. Macro-role of microRNA in gastric cancer. Digest Dis. 2012;30(3):255-67.

22. Mir R, Al Balawi IA, Duhier FMA. Involvement of microRNA-423 gene variability in breast Cancer progression in Saudi Arabia. Asian Pac J Cancer Prev. 2018;19(9):2581-9. https://doi.org/10.22034/APJCP.2018.19.9.2581.

23. Yan Z, Zhou Z, Li C, Yang X, Yang L, Dai S, et al. Polymorphisms in miRNA genes play roles in the initiation and development of cervical cancer. J Cancer. 2019;10(20):4747-53. https://doi.org/10.7150/jca.33486.

24. Ha M, Kim VN. Regulation of microRNA biogenesis. Nat Rev Mol Cell Biol. 2014;15(8):509-24. https://doi.org/10.1038/nrm3838.

25. Zhang J, Li YH, Liu HL, Zhang Y, Zhang QS, Li SZ. Correlations of MicroRNA21 gene polymorphisms with Chemosensitivity and prognosis of cervical Cancer. Am J Med Sci. 2018;356(6):544-51. https://doi.org/10.1016/j.amjms.2 018.08.014.

26. Li JH, Liu S, Zhou H, Qu LH, Yang JH. starBase v2.0: decoding miRNA-ceRNA, miRNA-ncRNA and protein-RNA interaction networks from large-scale CLIPSeq data. Nucleic Acids Res. 2014;42(Database issue):D92-7. https://doi.org/1 0.1093/nar/gkt1248.

27. Sole X, Guino E, Valls J, Iniesta R, Moreno V. SNPStats: a web tool for the analysis of association studies. Bioinformatics. 2006;22(15):1928-9. https:// doi.org/10.1093/bioinformatics/btl268.

28. Moazeni-Roodi A, Hashemi M. Association between miR-124-1 rs531564 polymorphism and risk of cancer: an updated meta-analysis of case-control studies. EXCLI J. 2018;17:608-19. https://doi.org/10.17179/excli2018-1419.

29. Bodal VK, Sangwan S, Bal MS, Kaur M, Sharma S, Kaur B. Association between Microrna 146a and Microrna 196a2 genes polymorphism and breast Cancer risk in north Indian women. Asian Pac J Cancer Prev. 2017; 18(9):2345-8. https://doi.org/10.22034/APJCP.2017.18.9.2345.

30. Melnik BC. MiR-21: an environmental driver of malignant melanoma? J Transl Med. 2015;13(1):202. https://doi.org/10.1186/s12967-015-0570-5.
31. Xu J, Zhang W, Lv Q, Zhu D. Overexpression of miR-21 promotes the proliferation and migration of cervical cancer cells via the inhibition of PTEN. Oncol Rep. 2015;33(6):3108-16. https://doi.org/10.3892/or.2015.3931.

32. Du G, Cao D, Meng L. miR-21 inhibitor suppresses cell proliferation and colony formation through regulating the PTEN/AKT pathway and improves paclitaxel sensitivity in cervical cancer cells. Mol Med Rep. 2017;15(5):2713-9. https://doi.org/10.3892/mmr.2017.6340.

33. Chacon-Cortes D, Smith RA, Haupt LM, Lea RA, Youl PH, Griffiths LR. Genetic association analysis of miRNA SNPs implicates MIR145 in breast cancer susceptibility. BMC Med Genet. 2015;16(1):107. https://doi.org/10.1186/s12 881-015-0248-0.

34. Ebrahimi F, Gopalan V, Wahab R, Lu CT, Smith RA, Lam AK. Deregulation of miR-126 expression in colorectal cancer pathogenesis and its clinical significance. Exp Cell Res. 2015;339(2):333-41. https://doi.org/10.1016/j. yexcr.2015.10.004

35. Wang CZ, Yuan P, Li Y. MiR-126 regulated breast cancer cell invasion by targeting ADAM9. Int J Clin Exp Pathol. 2015;8(6):6547-53.

36. Duan X, Yang Y, Zhang H, Liu B, Wei W, Wang L, et al. Polycyclic aromatic hydrocarbon exposure, miRNA genetic variations, and associated leukocyte mitochondrial DNA copy number: a cross-sectional study in China. Chemosphere. 2020;246:125773. https://doi.org/10.1016/j.chemosphere.201 9.125773

\section{Publisher's Note}

Springer Nature remains neutral with regard to jurisdictional claims in published maps and institutional affiliations.
Ready to submit your research? Choose BMC and benefit from:

- fast, convenient online submission

- thorough peer review by experienced researchers in your field

- rapid publication on acceptance

- support for research data, including large and complex data types

- gold Open Access which fosters wider collaboration and increased citations

- maximum visibility for your research: over $100 \mathrm{M}$ website views per year

At BMC, research is always in progress.

Learn more biomedcentral.com/submissions 